\title{
Adaptation of a Knowledge-Based Instructional Intervention to Accelerate Student Learning in Science and Early Literacy in Grades 1 and 2
}

\author{
Michael R. Vitale \\ East Carolina University \\ Nancy R. Romance \\ Florida Atlantic University
}

\begin{abstract}
This study focused on accelerating the development of in-depth science for students $(N=513)$ in grades 1-2 as a means for enhancing reading comprehension. Using an adaptation of a grade 35 cognitive-science-based, instructional model (Science IDEAS), the study implemented daily 45 minute instructional periods emphasizing in-depth, cumulative learning of science core-concept "clusters" that provided teachers with a thematic focus for all aspects of science instruction. Results confirmed the feasibility of implementing in-depth science instruction at the primary level and showed through analysis of covariance (ANCOVA) that experimental students obtained significantly higher achievement on nationally-normed lowa Tests of Basic Skills (ITBS) Reading and ITBS Science subtests than comparable controls. Curricular policy implications for increasing the instructional time for content-area instruction at the primary level are discussed.
\end{abstract}

Despite a continuing national emphasis on educational reform over the past 20 years, the low percentage of students achieving proficiency in science and reading comprehension has remained a continuing systemic problem (National Center for Educational Statistics, 2006, 2007; Schmidt, McKnight, Cogan, Jakwerth, \& Houang, 1999; Schmidt, McKnight, Houang, Wang, Wiley, Cogan, \& Wolfe, 2001). In particular, for content-area learning, the problem of meaningful learning from text is a significant barrier (American Federation of Teachers, 1997; Donahue, Voekl, Campbell, \& Mazzeo, 1999; Feldman, 2000; Snow, 2002), particularly with students who are at-risk and depend on school to learn.

Addressing these needs in a developmentally preventative fashion, the focus of this proof of concept study was to accelerate the development of in-depth science knowledge at the primary level (grades 1-2) as a means for enhancing reading comprehension (i.e., early literacy). In adapting a cognitive-science-based, instructional model (Science IDEAS) that has been shown effective (Romance \& Vitale, 1992, 2001, 2006, 2010, in press; Vitale \& Romance, 2006) in accelerating science understanding and reading comprehension proficiency of older children in grades 3-5, this study addressed a recognized need to develop student science understanding and comprehension proficiency at the primary levels (French, 2004; Gelman \& Brenneman, 
2004) in a fashion that would raise school achievement expectations for both at-risk and non at-risk students.

The theoretical and research foundations for the original grade 3-5 Science IDEAS intervention are based on well-accepted findings from cognitive science that, in turn, are directly applicable to the grade 1-2 Science IDEAS adaptation used in the present study (Vitale \& Romance, 2006). As a knowledge-based instructional model, Science IDEAS requires (a) the explicit representation of the knowledge to be taught and learned in the form of core concepts and concept relationships, and (b) subsequent linkage of all instructional methods and activities chosen for use by teachers to the same framework of core concept relationships. In implementing the model, teachers are able to select and use a wide variety of reading and language arts and hands-on activities that expand student in-depth science knowledge about what is being learned. This instructional framework enables teachers to adopt a cumulative inquiry style that (a) emphasizes for students how information learned over the sequence of different activities results in additional knowledge and understanding and (b) guides students to relate what they have learned as elaborations of the core concepts taught.

Central to the foundational ideas underlying the Science IDEAS model is a report by the National Academy Press, How People Learn, edited by Bransford, Brown, and Cocking (2000). As an emergent research trend, Bransford et al. stressed the development and access of core concepts and concept relationships as critical elements in the development of any form of expertise. In a parallel fashion, the Science IDEAS model emphasizes using the core concepts that reflect the logical structure of the discipline as an instructional architecture for building cumulative, meaningful learning as a form of expertise (French, 2004; Schmidt et al., 2001). A number of other articles (Beane, 1995; Ellis, 2001; Hirsch, 2001; Schug \& Cross, 1998; Yore, 2000) have discussed curricular issues and findings that support curriculum interventions represented by knowledge-based instructional approaches such as that in the present study.

The National Reading Panel (2000, p. 464) recognized the original grade 3-5 Science IDEAS study (Romance \& Vitale, 1992) as one of the few scientifically-based research studies demonstrating combined student achievement in science and reading comprehension. Romance and Vitale (2001) replicated and extended their initial study over an additional two-year period and obtained the same achievement outcomes in science and reading. Other research initiatives have obtained positive outcomes as well. Klentschy and Molina-De La Torre (2004) found a significant impact of the number of years of science-focused instruction in grades K-5 on student achievement on stateadministered reading comprehension tests. Guthrie and Ozgungor (2002) and Guthrie, Wigfield, and Perencevich (2004) showed that content-oriented reading materials at the upper elementary levels significantly improved both general reading proficiency and student motivation to engage in reading. Armbruster and Osborn (2001) summarized research findings demonstrating positive student achievement in reading comprehension resulting from integrating science content with reading and language 
arts. Cumulative research reported by Block and Pressley (2002) showed that many of the strategies encompassed in the Science IDEAS model (Romance \& Vitale, 2006) and the present adaptation emphasizing science and literacy (e.g., relating prior knowledge, mental imagery, questioning, summarization) were effective in improving reading comprehension.

With the preceding in mind, the intervention in the present study focused on the development of meaningful knowledge in science in a fashion that is consistent with emerging literacy trends (Palmer \& Stewart, 2003) that emphasize the use of informational text for developing comprehension proficiency at the primary levels (for related views see Holliday, 2004; Klentschy \& Molina-De La Torre, 2004; Ogle \& Blachowicz, 2002; Gould, Weeks, \& Evans, 2003). The specific research question investigated in the study was whether the adaptation of the grade 3-5 Science IDEAS model to grades 1-2 would result in the concurrent acceleration of student achievement in science and reading comprehension and whether the model would have a consistent effect on diverse students that varied in gender, ethnicity, and socio-economic status (SES).

\section{Method}

\section{Participants}

The study was implemented in all sections of grades 1-2 in two elementary schools (schools $A$ and $B$ ) which were representative of the student ethnic diversity (Black 29\%, Hispanic 19\%, Other 5\%; and socio-economic status (40\% free and reduced lunch) in a large (185,000 students) school system in southeastern Florida. Students in two demographically-similar schools (schools C and D) served as controls. Table 1 summarizes the demographic characteristics of the participants.

Table 1.

Major Demographic Characteristics of Participants

\begin{tabular}{lccccccc}
\hline Group & School & $\begin{array}{c}\text { Teachers } \\
\text { Sreatment }\end{array}$ & S Students & $\begin{array}{c}\text { Male } \\
\%\end{array}$ & $\begin{array}{c}\text { White } \\
\%\end{array}$ & $\begin{array}{c}\text { Black } \\
\%\end{array}$ & $\begin{array}{c}\text { Hispanic } \\
\%\end{array}$ \\
& B & 9 & 114 & 59 & 49 & 22 & 29 \\
Controls & 6 & 97 & 45 & 27 & 19 & 54 \\
& C & 11 & 166 & 58 & 51 & 22 & 27 \\
& D & 7 & 136 & 49 & 14 & 19 & 67 \\
\hline
\end{tabular}




\section{Instrumentation}

The nationally-normed lowa Tests of Basic Skills (ITBS) Reading Comprehension and Science subtests (Level 7 for grade 1, Level 8 for grade 2) were administered as measures of student learning by classroom teachers under supervision of the researchers. The ITBS is a nationally-normed achievement test battery used by a large number of U.S. schools. The ITBS norms include developmental and gradeequivalent scale scores.

\section{Experimental Intervention}

The study was implemented over an 8-week period during which daily 45-minute lessons emphasized the core-concept "clusters" (e.g., grade 1- Solids and liquids, Using your senses, Measuring tools, Gases, Phases of matter, Forms of energy, Energy transfer, Pushes and pulls, Types of forces, Simple machines; grade 2- States of matter, Using your senses, Measuring tools, Physical changes, Forms of energy, Energy transfer, Pushes and pulls, Simple machines, Heat energy). Unlike the grade 35 Science IDEAS model which replaces traditional reading and language arts instruction (Romance \& Vitale, 2001), in the present study daily 45-minute instructional blocks in grades 1-2 were in addition to the district-required 90 minutes of reading and language arts instruction implemented in experimental and control schools. In using core science concept "clusters" as a curricular focus, instructional activities in grade 1 emphasized teacher-guided student reading of age-appropriate science materials complemented by hands-on activities, with follow-up simple concept mapping and journaling. In grade 2, the instructional activities included all of the grade 1 activities, but placed an increased emphasis on student reading and comprehension of science materials, concept mapping to represent knowledge learned, and writing to communicate what had been learned.

Participating teachers completed a three-day professional development "start-up" module. Subsequently, teachers participated in two additional half-days of follow-up training. The focus of professional development was to insure teachers had (a) a sound understanding of the science concepts they were to teach, (b) proficiency on basic elements of the Science IDEAS model (e.g., age-appropriate hands-on activities, reading comprehension guidance, journaling, simple concept mapping), and (c) sufficient assistance in curriculum and lesson planning that focused on the science concept clusters to be taught. Project staff informally monitored all participating classrooms on a regular, continuing basis. Implementation fidelity forms adapted for use from the grade 3-5 Science IDEAS implementation model were used to focus monitoring (e.g., classroom displays, teacher use of Science IDEAS elements and activities, active student engagement in learning). The fidelity monitoring process also provided the project staff with a basis for evaluating teacher implementation needs and providing follow-up support. 
In comparison to experimental classrooms, teachers in control classrooms implemented their regular district-adopted, basal-oriented reading, language arts, and science programs.

\section{Design, Analysis, and Procedure}

The framework for the overall research design and analysis consisted of a 2 (treatment or control) $\times 2$ (grade level) $\times 3$ (ethnicity) $\times 2$ (gender) $\times 2$ (time of test) factorial with repeated measures on the last factor. Since the two academic response measures were different, separate univariate linear model ANCOVAs were conducted for each of the two different achievement outcomes.

All student achievement and demographic data were collected in collaboration with the district research department. The resulting database for data analysis used codes to assure that the identities of schools, teachers, and students could not be determined. For use in the linear models ANCOVA analyses, all main effects and interactions were coded as contrasts for input to the statistical analysis software. Throughout the study, researchers monitored grades 1 and 2 science instruction to insure implementation fidelity of the model and to provide teacher support as needed.

Fidelity of implementation was assessed through two classroom observations conducted approximately three weeks apart during the eight-week intervention. The fidelity methodology was developed for use in grades 3-5 in an earlier study (Vitale \& Romance, 2009) in which observers rated the instructional activities observed using a four-point scale $(1=$ model not implemented, $2=$ model partially implemented, $3=$ model implemented, $4=$ model well-implemented). Reliability (.82) was estimated as percent of agreement of implemented (3 or 4) vs. not or partially implemented (1or 2) of paired observers visiting the same classroom within a 5-day period. Assessment of implementation fidelity involved a variety of formal and informal observations leading to clinical judgments. In general, grade 1-2 teachers were judged as effective in implementing the grade 1-2 Science IDEAS model throughout the duration of the study.

\section{Results}

\section{Descriptive Statistics for Treatment and Control Schools}

Table 2 summarizes the mean grade-equivalent performance in the treatment and control schools for the academic outcome measures by grade. 
Table 2.

Descriptive Statistics of Academic Outcome Measures by School and Grade

\begin{tabular}{|c|c|c|c|c|c|c|}
\hline \multirow{3}{*}{$\begin{array}{l}\text { Grade and } \\
\text { Treatment Group }\end{array}$} & \multirow[t]{2}{*}{ School } & \multirow[b]{2}{*}{$N$} & \multicolumn{2}{|c|}{$\begin{array}{c}\text { ITBS Reading }^{1} \\
\%\end{array}$} & \multicolumn{2}{|c|}{$\begin{array}{c}\text { ITBS Science } \\
\%\end{array}$} \\
\hline & & & $M$ & $S D$ & $M$ & $S D$ \\
\hline & & & & & & \\
\hline \multirow[t]{2}{*}{ Treatment } & A & 54 & 1.6 & .72 & 1.6 & .92 \\
\hline & B & 56 & 1.6 & .66 & 1.1 & .83 \\
\hline \multirow[t]{2}{*}{ Controls } & C & 99 & 1.4 & .83 & 1.3 & .80 \\
\hline & D & 83 & 1.4 & .62 & 1.2 & .76 \\
\hline \multicolumn{7}{|l|}{ Grade 2: } \\
\hline \multirow[t]{2}{*}{ Treatment } & A & 43 & 2.6 & 1.5 & 2.2 & 1.7 \\
\hline & B & 58 & 2.5 & .90 & 1.8 & 1.3 \\
\hline \multirow[t]{2}{*}{ Controls } & C & 67 & 2.1 & 1.1 & 1.8 & 1.5 \\
\hline & D & 53 & 1.2 & .42 & 1.5 & 1.3 \\
\hline
\end{tabular}

Note. 'ITBS Reading mean grade-equivalents. ${ }^{2}$ ITBS Science mean grade-equivalents.

\section{Student Achievement Outcomes}

Table 3 summarizes the results of the linear models ANCOVA analysis for ITBS Reading and ITBS Science. In interpreting Table 3 it is important to note two aspects of the analysis models used. First, preliminary analyses showed that there was no overall effect of Gender and that Gender did not interact with the experimental treatment. As a result, Gender was fit to a simplified model without interactions involving Gender with other variables. Second, because SES (free and reduced lunch) was highly correlated with ethnicity (white vs. non-white), it was not included in the statistical models used (i.e., minority status should be interpreted as closely related to low-SES in the analyses). 
Table 3.

Results of Linear Models Analysis of Achievement Outcomes in Reading and Science

\begin{tabular}{lll}
\hline Model Component & ITBS Reading & ITBS Science \\
\hline Main Effects: & & \\
Treatment (Trt.) & $F(1,500)=23.155^{* *}$ & $F(1,500)=6.11^{*}$ \\
Grade & $F(1,500)=44.38^{* *}$ & $F(1,500)=20.82^{* *}$ \\
Ethnicity & $F(2,500)=9.82^{* *}$ & $F(2,500)=0.62$ \\
Gender & $F(1,500)=3.41$ & $F(1,500)=0.03$ \\
Interactions: & & \\
Trt. x Grade & $F(1,500)=12.39^{* *}$ & $F(1,500)=1.91$ \\
Trt. x Ethnicity & $F(2,500)=0.77$ & $F(2,500)=1.25$ \\
Grade x Ethnicity & $F(2,500)=2.80$ & $F(2,500)=1.89$ \\
Trt. x Grade x Ethnicity & $F(2,500)=0.23$ & $F(2,500)=1.22$ \\
\hline
\end{tabular}

Note. Treatment $=$ Science IDEAS vs. Controls.

Simple effects analysis of ITBS Reading achievement by grade found the treatment significant in grade 2 , not in grade 1 (see text for details).

${ }^{*} p<.05 .{ }^{* *} p<.01$.

As Table 3 shows, the experimental treatment was significant for both of the ITBS Reading and Science academic outcome measures. Adjusted means obtained through the ANCOVA found differences in favor of the treatment students for both ITBS Reading [+.42 grade equivalents (GE)] and ITBS Science (+.28 GE). Within the context of ANCOVA, these adjusted mean differences show the achievement differences between the treatment (Science IDEAS) and control groups that remain after differences in achievement that were predictable from the covariates have been statistically removed. As Table 3 also shows, the effect of Grade was significant for the ITBS Reading and Science measures with grade 2 students showing higher achievement. With regard to other main effects, significant differences in ethnicity were found for ITBS Reading. In order to determine the differences due to ethnicity more precisely, follow-up statistical analyses were conducted comparing White to non-White (Black, Hispanic) and Black to Hispanic students. These individual degree of freedom tests of the adjusted mean achievement by ethnicity found the significant differences within the overall ethnicity factor were due to a White vs. non-White comparison (mean difference on ITBS Reading $=+.38$ GE in favor of White students, $F(1,500)=19.27, p<$ .01 ), with no difference between Black and Hispanic students. The remaining significant effect consisted of a Treatment $x$ Grade interaction for ITBS Reading. This interaction indicated that the effect of the treatment was not the same in the two grade levels in the study. In order to determine the effects of the treatment in each grade separately, a follow-up simple effects analysis showed that the experimental treatment was significant only for grade 2 students (Grade 1: Science IDEAS vs. Controls difference $=+.11 \mathrm{GE}, F$ $(1,500)=1.54, n s ;$ Grade 2 : Science IDEAS vs. Controls difference $=+.72 \mathrm{GE}, F(1$, $500)=34.19, p<.01)$. 
In interpreting the findings, it is important to note that although significant differences on ITBS Reading were found for ethnicity, there were no interaction effects between ethnicity and the experimental intervention. This finding paralleled that of earlier Science IDEAS research (Romance \& Vitale, 2001) and indicated that although there were achievement differences on ITBS Reading between White and non-White students, the effect of the grade 1-2 Science IDEAS intervention had a consistent overall effect on all students. Again, it should be noted that in the present analyses, non-White ethnicity (i.e., being Black or Hispanic) was highly correlated with low-SES as indicated by free and reduced lunch eligibility which, in turn, is indicative of being at risk for low academic achievement.

\section{Discussion}

The results of this proof of concept study are suggestive of several key issues involving grade 1-2 instructional priorities. Contrary to a review by Appleton (2007) which reported substantial barriers for elementary science instruction, the findings of the present study demonstrated not only the feasibility of implementing a strong 45 minuteper-day emphasis on science in grades 1-2, but also a significant positive impact on norm-referenced achievement in both reading in grade 2 and science in grades 1-2 for students of all ethnicities. These findings are consistent with research findings reported by Romance and Vitale $(1992,2001)$ at the grade 3-5 level and with other literature emphasizing the importance of science instruction at the elementary level (Armbruster \& Osborn, 2001; Guthrie \& Ozgungor, 2002; Guthrie et al., 2004; Klentschy \& Molina-De La Torre, 2004).

A major emphasis in the present grade 1-2 intervention was that science knowledge provided a meaningful context through which students at the primary levels were able to experience cumulative meaningful learning in a fashion that enhances their capacity for comprehension. In this regard, French (2004) reported the feasibility of a curricular approach in which science experiences provide a rich learning context for an early childhood curriculum that resulted in early literacy development as well as science learning. Gelman and Brenneman (2004) showed how a preschool science program which incorporated guided hands-on activities could be used as a framework for instruction that engendered the development of domain specific knowledge in young children. In working with 3 to 6 year olds, Smith (2001) described how the active involvement of young children in gaining science knowledge is naturally motivating (Conezio \& French, 2002) if topics are approached with sufficient depth and time, a position consistent with the 1995 National Science Education Standards (Rakow \& Bell, 1998). In other representative work, Gould et al. (2003) described an approach for early science instruction with gifted students; Tytler and Peterson (2000) summarized the meaningful changes in 5-year-olds' explanations of evaporation as a result of extended in-depth science instruction; Jones and Courtney (2002) addressed the processes of curricular planning for instruction and assessment in early science learning; Armga et al. (2002) and Colker (2002) suggested guidelines for teaching science in early childhood 
settings; and Lee, Lostoski, and Williams (2000) described the benefits of schoolwide thematically-oriented instruction in science.

Focusing on the development of meaningful knowledge in science as a means for enhancing student comprehension is also consistent with emerging literacy trends (Palmer \& Stewart, 2003) that emphasize the use of informational text at the primary level (Holliday, 2004; Klentschy \& Molina-De La Torre, 2004; Ogle \& Blachowicz, 2002; Gould et al., 2003). In studying the lack of informational text to which young children are exposed in school settings, Duke and her colleagues (Duke \& Pearson, 2002; Pearson \& Duke, 2002) noted that the terms "comprehension instruction" and "primary grades" seldom appeared together. As advocates of increasing primary student involvement with informational material, Pearson and Duke reported that teachers erroneously believe that instruction involving comprehension must wait until students develop decoding proficiency in reading. Pearson and Duke also listed and refuted major unsupported beliefs that serve as barriers to the use of informational text at the primary grades (e.g., young children cannot handle them and are uninterested; comprehension is best at upper elementary grades). Given these conditions, it is not surprising that Duke and others (Duke, 2000, 2010; Duke, Bennett-Armistead, \& Roberts, 2003a, Duke, Martineau, Frank, \& Bennett-Armistead, 2003b; Pearson, Moje, \& Greenleaf, 2010; Pressley, Rankin, \& Yokoi, 1996; Walsh, 2003) found that primary students have minimal opportunities for exposure to learning that involves meaningful comprehension, despite an extensive research base that provides guidance on how such instruction should be (and should not be) implemented effectively (Asoko, 2002; Carnine, 1993, 1995; Ginsberg \& Gollbeck, 2004; Hirsch, 2003, 2006; Jones et al., 1999; Klentschy \& Molina-De La Torre, 2004; Pretti-Frontczak, Barr, Macy, \& Carter, 2003; Sandell, 2003; Thompson \& O'Quinn, 2001).

\section{Research Implications and Limitations}

Overall, the findings of the present study when considered with prior research (Romance \& Vitale, 2001, 2010; Vitale, Romance, \& Klentschy, 2006) contribute to the support of a general curriculum policy at the grade K-5 levels that would advocate greater amounts instructional time being allocated to the forms of content-area learning (such as science) that involve meaningful cumulative learning. Because the implications of the study are directly relevant to enhancing the preparation of grade 1-2 students, the study also advanced knowledge that bridges research and practice by applying a broad set of interdisciplinary research findings to a systemic issue in education reform (Romance \& Vitale, in press). More specifically, the interdependence of the meaningful learning of science and the development of comprehension proficiency at the primary level are important issues that further research should address. In this regard, the results of the study are supportive of the feasibility of increasing the amount of contentarea instruction in science at the primary (1-2) level. In considering implications for research, policy, and practice, several limitations of the present study should be noted. This study consisted of only an 8-week intervention and, despite implementation on a schoolwide basis in grades 1-2, only two schools were involved. While the results of this 
study should be considered as strong evidence in the form of proof of concept, it is important for the findings to be replicated and extended to greater numbers of schools and to longer implementations of the intervention to establish generalizability of the findings. In particular, a strong research-based foundation for curricular policy to increase the amount of instructional time allocated to science in grades 1-2, would require future studies that would investigate the effects (a) of implementing the present model over a full school year and (b) tracking the cumulative achievement of students experiencing the model in both grades 1 and 2 to grade 3.

Note

The research reported here was supported by the National Science Foundation through Grant REC 0228353 to Florida Atlantic University. The opinions expressed are those of the authors and do not represent views of the National Science Foundation.

\section{References}

American Federation of Teachers (AFT). (1997). Making standards matter 1997. An annual fifty state report of efforts to raise academic standards. Washington, DC: Author. GS Search

Armbruster, B. B., \& Osborn, J. H. (2001). Reading instruction and assessment: Understanding IRA standards. New York, NY: Wiley.

Armga, C., Dillon, S., Jamsek, M., Morgan, E. L., Peyton, D., \& Speranza, H. (2002). Tips for helping children do science. Texas Child Care, 26(3), 2-7. GS Search

Appleton, K. (2007). Elementary science teaching. In S. Abell \& N. Lederman (Eds.), Handbook of research on science education (pp. 493-536). Mahwah, NJ: Erlbaum.

Asoko, H. (2002). Developing conceptual understanding in primary science. Cambridge Journal of Education, 32(2), 153-164. Cross Ref GS Search

Beane, J. A. (1995). Curriculum integration and the disciplines of knowledge. Phi Delta Kappan, 76(8), 616-622. GS Search

Block, C. C., \& Pressley, M. (Eds.). (2002). Comprehension instruction: Researchbased best practices. New York, NY: Guilford Press.

Bransford, J. D., Brown, A. L., \& Cocking, R. R. (Eds.). (2000). How people learn. Washington, DC: National Academy Press.

Carnine, D. (1993). Facts over fads. Education Week, 13(14), 40. 
Carnine, D. (1995). Standards for educational leaders: Could California's reading results lead the way? Education Week, 15(6), 52-53.

Colker, L. J. (2002). Teaching and learning about science. Young Children, 57(5), 10$11,47$.

Conezio, K., \& French, L. (2002). Science in the preschool classroom: Capitalizing on children's fascination with the everyday world to foster language and literacy development. Young Children, 57(5), 12-18. GS Search

Donahue, P. L., Voekl, K. E., Campbell, J. R., \& Mazzeo, J. (1999). NAEP 1998 reading report card for the states. National Center for Educational Statistics. Washington, DC: U.S. Department of Education. GS Search

Duke, N. K. (2000). 3.6 minutes per day. The scarcity of informational texts in first grade. Reading Research Quarterly. 35(2), 202-224. CrossRef GS Search

Duke, N. K. (2010). The real-world reading and writing U.S. children need. Kappan, 91(5), 68-71. GS Search

Duke, N. K., Bennett-Armistead, V. S., \& Roberts, E. M. (2003a). Filling the nonfiction void. American Educator, 27(1), 30-35. GS Search

Duke, N. K., Martineau, J. A., Frank, K. A., \& Bennett-Armistead, V. S. (2003b). 33.6 minutes per day: The impact of including more information text in first grade. Unpublished manuscript, Michigan State University.

Duke, N., \& Pearson, P. D. (2002). Effective practices for developing reading comprehension. In A. Farstrup \& S. Samuels (Eds.), What research has to say about reading instruction (pp.205-242). Newark, DE: International Reading Association. GS Search

Ellis, A. K. (2001). Research on educational innovations. Larchmont, NY: Eye on Education.

Feldman, S. (2000). Standards are working: But states and districts need to make some mid-course corrections. American Educator, 24(3), 5-7.

French, L. (2004). Science as the center of a coherent, integrated early childhood curriculum. Early Childhood Research Quarterly, 19(1), 138-149. CrossRef GS Search

Gelman, R., \& Brenneman, K. (2004). Science learning pathways for young children. Early Childhood Research Quarterly, 19(1) 150-158. CrossRef GS Search 
Ginsburg, H. P., \& Golbeck, S. L. (2004). Thoughts on the future of research on mathematics and science learning and education. Early Childhood Research Quarterly, 19(1), 190-200. CrossRef GS Search

Gould, C. J., Weeks, V., \& Evans, S. (2003). Science starts early. Gifted Child Today Magazine, 26(3), 38-41, 65. GS Search

Guthrie, J. T., \& Ozgungor, S. (2002). Instructional contexts for reading engagement. In C. Block \& M. Pressley (Eds.), Comprehension instruction: Research-based best practices (pp. 275-288). New York, NY: Guilford Press.

Guthrie, J. T., Wigfield, R., \& Perencevich, K. C. (Eds.). (2004). Motivating reading comprehension: Concept-oriented reading instruction. Mahwah, NJ: Earlbaum.

Hirsch, E. D. (2001). Seeking breadth and depth in the curriculum. Educational Leadership, 59(2), 21-25. GS Search

Hirsch, E. D. (2003). Reading comprehension requires knowledge - of words and the world: Scientific insights into the fourth-grade slump and stagnant reading comprehension. American Educator, 27(1), 10-29. GS Search

Hirsch, E. D. (2006). The knowledge deficit. Boston: Houghton Mifflin.

Holliday, W. G. (2004). Choosing science textbooks: Connecting science research to common sense. In W. Saul (Ed.), Crossing borders in literacy and science instruction (pp. 383-394). Newark, DE: International Reading Association and NSTA Press.

Jones, J., \& Courtney, R. (2002). Documenting early science learning. Young Children, $57(5), 34-38,40$. GS Search

Jones, M. G., Jones, B. D., Hardin, B., Chapman, L., Yarbrough, T., \& Davis, M. (1999). The impact of high-stakes testing on teachers and students in North Carolina. Phi Delta Kappan, 81(3), 199-203. GS Search

Klentschy, M. P., \& Molina-De La Torre, E. (2004). Students' science notebooks and the inquiry process. In E. Saul (Ed.), Crossing borders in literacy and science instruction: Perspectives on theory and practice (pp. 340-354). Newark, DE: International Reading Association.

Lee, M., Lostoski, M., \& Williams, K. (2000). Diving into a schoolwide science theme. Science and Children, 38(1), 31-35. GS Search

National Center for Educational Statistics (NCES). (2006). The nation's report card: Science 2005. Washington, DC: U.S. Department of Education. 
National Center for Educational Statistics (NCES). (2007). The nation's report card: 12grade reading and mathematics 2005. Washington, DC: U.S. Department of Education.

National Reading Panel. (2000). Teaching children to read: An evidence-based assessment of scientific research literature on reading and its implications for reading instruction. Jessup, MD: National Institute for Literacy.

Ogle, D. \& Blachowicz, C. L. Z. (2002). Beyond literature circles: Helping students comprehend informational texts. In C. Block, \& M. Pressley (Eds.), Comprehension instruction (pp. 247-258). New York, NY: Guilford Press.

Palmer, R. G., \& Stewart, R. (2003). Nonfiction trade book use in primary grades. The Reading Teacher, 57(1), 38-48. GS Search

Pearson, P. D., \& Duke, N. (2002). Comprehension instruction in the primary grades. In C. Block \& M. Pressley (Eds.), Comprehension instruction: Research-based best practices (pp. 247-258). New York, NY: Guilford Press.

Pearson, P. D., Moje, E., \& Greenleaf, C. (2010). Literacy and science: Each in the service of the other. Science, 328(5977), 459-463. CrossRef GS Search

Pressley, M., Rankin, J., \& Yokoi, L. (1996). A survey of instructional practices of primary teachers nominated as effective in promoting literacy. Elementary School Journal, 96(4), 363-384. CrossRef GS Search

Pretti-Frontczak, K. L., Barr, D. M., Macy, M., \& Carter, A. (2003). Research and resources related to activity-based intervention, embedded learning opportunities, and routines-based instruction: An annotated bibliography. Topics in Early Childhood Special Education, 23(1), 29-39. CrossRef GS Search

Rakow, S. J., \& Bell, M. J. (1998). Science and young children: The message from the National Science Education Standards. Childhood Education, 74(3), 164-167. GS Search

Romance, N. R., \& Vitale, M. R. (1992). A curriculum strategy that expands time for indepth elementary science instruction by using science-based reading strategies: Effects of a year-long study in Grade 4. Journal of Research in Science Teaching, 29(6), 545-554. CrossRef GS Search

Romance, N. R., \& Vitale, M. R. (2001). Implementing an in-depth expanded science model in elementary schools: Multi-year findings, research issues, and policy implications. International Journal of Science Education, 23(4), 373-404. GS Search 
Romance, N. R., \& Vitale, M. R. (2006). Science IDEAS: Making the case for integrating reading and writing in elementary science as a key element in school reform. In R. Douglas, M. Klentschy, \& K. Worth (Eds.), Linking science and literacy in the K-8 classroom (pp. 394-405). Arlington, VA: NSTA Press.

Romance, N. R., \& Vitale, M. R. (2010). A research-based instructional model for integrating meaningful learning in elementary science and reading comprehension. In N. Stein \& S. Raudenbush (Eds.), Developmental cognitive science goes to school (pp. 127-142). New York, NY: Rutledge.

Romance, N. R., \& Vitale, M. R. (in press). Interdisciplinary perspectives linking science and literacy in grades K-5: Implications for policy and practice. In K. Tobin \& D. Treagust (Eds.), Second international handbook of science education. Dordrecht, Netherlands: Kluwer Academic Publishers.

Sandall, B. R. (2003). Elementary science: Where are we now? Journal of Elementary Science Education, 15(2), 13-30. CrossRef GS Search

Schmidt, W. H., McKnight, C., Cogan, L. S., Jakwerth, P. M., \& Houang, R. T. (1999). Facing the consequences: Using TIMSS for a closer look at U.S. mathematics and science education. Boston, MA: Kluwer Academic Publishers.

Schmidt, W. H., McKnight, C. C., Houang, R. T., Wang, H. C., Wiley, D. E., Cogan, L. S., Wolfe, R. G. (2001). Why schools matter: A cross-national comparison of curriculum and learning. San Francisco, CA: Jossey-Bass.

Schug, M. C., \& Cross, B. (1998). The dark side of curriculum integration in social studies. Social Studies, 89(2), 54-57. CrossRef GS Search

Smith, A. (2001). Early childhood - a wonderful time for science learning. Investigating: Australian Primary \& Junior Science Journal, 17(2), 18-21. GS Search

Snow, C. E. (2002). Reading for understanding: Toward a research and development program in reading comprehension. Santa Monica, CA: RAND.

Thompson, C. L., \& O'Quinn, D. (2001). Eliminating the black-white achievement gap: A summary of research. Chapel Hill, NC: North Carolina Educational Research Council.

Tytler, R., \& Peterson, S. (2000). Deconstructing learning in science - young children's responses to a classroom sequence on evaporation. Research in Science Education, 30(4), 339-355. CrossRef GS Search 
Vitale, M. R., \& Romance, N. R. (2006). Research in science education: An interdisciplinary perspective. In J. Rhoton and P. Shane (Eds.), Teaching science in the $21^{\text {st }}$ Century (pp. 329-351). Arlington VA: NSTA Press.

Vitale, M. R., \& Romance, N. R. (2009). A research-based model for integrating elementary science and reading comprehension: Implications for research and practice. Paper presented at the Annual Meeting of the American Educational Research Association, San Diego, CA.

Vitale, M. R., Romance, N. R., \& Klentschy, M. (2006). Improving school reform by changing curriculum policy toward content-area instruction in elementary schools. Paper presented at the Annual Meeting of the American Educational Research Association, San Francisco, CA

Walsh, K. (2003). Basal readers: The lost opportunity to build the knowledge that propels comprehension. American Educator, 27(1), 24-27. GS Search

Yore, L. (2000). Enhancing science literacy for all students with embedded reading instruction and writing-to-learn activities. Journal of Deaf Students and Deaf Education, 5(1), 105-12. CrossRef GS Search

\section{About the Authors}

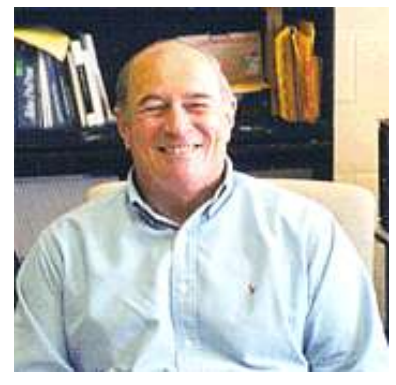

Michael R. Vitale, Ph.D., is a Professor in the College of Education at East Carolina University. He received his Ph.D. in Educational Research/Instructional Psychology from Florida State University. He has been a faculty member in Educational Psychology at the University of Hawaii and in Educational Technology at Florida Atlantic University. His public school experience includes serving as Director of Applied Research and as Director of Instructional Technology for the Dallas (TX) Independent School District. His research interests include applications that combine applied learning theory, instructional design frameworks, and cognitive science principles to problems in the development of student content-oriented reading comprehension proficiency and science understanding in K-8 school settings. E-mail: vitalem@ecu.edu

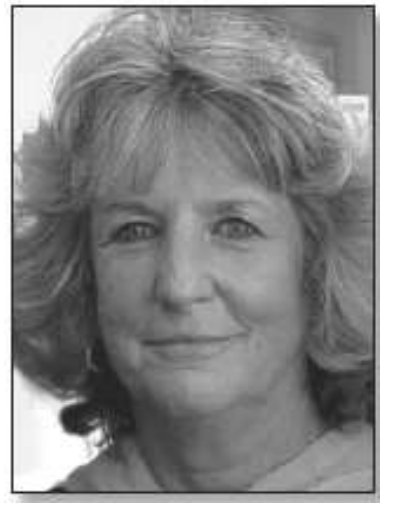

Nancy R. Romance, Ed.D., is a Professor in the College of Education at Florida Atlantic University. She received her doctorate in Educational Leadership from Florida Atlantic University and her M.S. in Biology/Secondary Science from the State University of New York at Buffalo. Her public school experience includes serving as Director of K-12 Science, an Assistant Middle School Principal, and a Middle School Science Teacher, all for the Broward (FL) School System. She also served as Director for the Southeastern Florida Technical Assistance Center for the Florida Department of Education. Her research interests include improving the effectiveness of science teaching at the K-12 and Post-Secondary Levels and demonstrating the effectiveness of cognitive-science-based instructional models in grades K-2 and grades 3-5 in which reading and language arts are embedded in science instruction. E-mail: romance@fau.edu 